Agata Adamska

Szkoła Gtówna Handlowa w Warszawie

\title{
Modele rozwoju rynku kapitałowego w Państwach Europy Środkowo-Wschodniej
}

\author{
MODELS OF DEVELOPMENT OF THE CAPITAL \\ MARKET IN THE COUNTRIES OF CENTRAL \\ AND EASTERN EUROPE
}

\begin{abstract}
Dobrze rozwinięte rynki kapitałowe stanowiq ważny element gospodarki, jako źródto finansowania przedsiębiorstw komplementarne wobec systemu bankowego. Ponadto petniq inne ważne funkcje: pozwalaja na wycenę kapitału i ryzyka, ułatwiajq transfer własności akcji, ponadto stanowiq miejsce inwestycji $i$ spekulacji. Rynki państw rozwiniętych sq często poddawane różnorodnym analizom, które pozwalaja ocenić zarówno stan rozwoju tych rynków, jak $i$ ich funkcjonowanie. $W$ odniesieniu do rynków wschodzacych takich analiz jest znacznie mniej. Najsłabiej zbadane w tym zakresie sq rynki Europy Środkowo-Wschodniej. W celu przynajmniej częściowego wypetnienia tej luki przeprowadzono analizę rozwoju zorganizowanych rynków giełdowych $w$ tych państw $w$ okresie lat 2006-2017. Przyjęto szeroki zakres terytorialny badaniem objęto: Albanię, Białoruś, Bośnię i Hercegowinę, Bułgarię, Chorwację, Czarnogórę, Czechy, Estonię, Litwę, Lotwę, Macedonię, Polskę, Rumunię, Serbię, Stowację, Stowenię, Ukrainę, Węry.

Dane wykorzystane do przeprowadzenia analizy pochodzity z dużej liczby źródet wtórnych, takich jak strony internetowe samych giełd, ich raporty roczne, publikacje naukowe, opracowania $i$ raporty firm doradczych, a także bazy danych organizacji międzynarodowych. Wyniki przeprowadzonej analizy wskazuja, że giełdy z regionu Europy Środkowo-Wschodniej podażaty trzema drogami: (1) wybierały rozwój organiczny, stawiajqc na samodzielność operacyjna, (2) przystępowaty do aliansów regionalnych, (3) stawały się uczestnikami aliansów globalnych. Wyniki badań dotyczqcych zmian, jakie zaszły na tych giełdach między rokiem 2006 a 2017 dowodza, że żadne z rozwiqzań nie prowadziło do petnego sukcesu. Wyniki te wskazuja również, że giełdy generalnie lepiej radzily sobie z przezwyciężaniem barier po stronie podażowej (na części rynków wzrosła liczba emitentów i średnia wartość spótki), niż popytowej (niemal na wszystkich giełdach spadła zarówno wielkość, jak i prędkość obrotu).
\end{abstract}

Slowa kluczowe: Europa Środkowo-Wschodnia, rynek kapitałowy, giełda papierów wartościowych, prędkość obrotu, zorganizowany rynek

\section{Wprowadzenie}

Jedną z istotnych instytucji kapitalizmu jest rynek kapitałowy. I tak, jak różne są formy, rodzaje i typy kapitalizmu ${ }^{1}$, tak też różne są odmiany rynku kapitałowego. Co więcej, ani

\footnotetext{
${ }^{1}$ B. Jessop: Rethinking the diversity of capitalism: varieties of capitalism, variegated capitalism, and the world market, in: C. Lane, G.T. Wood (eds.), Capitalist Diversity and Diversity within Capitalism, Routledge, London 2011, pp. 209-237.
} 
kapitalizm jako ustrój, ani rynki kapitałowe, nie pozostają statyczne, lecz podlegają ustawicznym zmianom ewolucyjnym oraz szokowym dostosowaniom ${ }^{2}$. Ważne jest więc śledzenie zachodzących zmian $\mathrm{i}$ dokonywanie porównań zarówno $\mathrm{w}$ ujęciu przestrzennym, jak i czasowym. Dotyczy to zwłaszcza przekształceń zachodzących w relatywnie słabo zbadanych regionach, takich jak państwa Europy ŚrodkowoWschodniej. Odpowiadając na tę potrzebę przeprowadzono analizę porównawczą rozwoju rynków kapitałowych w tych państwach, ze szczególnym uwzględnieniem giełd papierów wartościowych, na których przedmiotem obrotu są akcje. Jej wyniki przedstawiono w niniejszym opracowaniu.

Meandry historii powodują że trudno jednoznacznie stwierdzić, gdzie przebiegają granice samej Europy (geograficznie jest to nieco inny obszar, niż politycznie), a jeszcze większe problemy stwarza próba jednoznacznego wyodrębnienia regionu Europy Środkowo-Wschodniej ${ }^{3}$. Popularność pojęcia Europa Srodkowo-Wschodnia w kontekście geopolitycznym zaczęła rosnąć pod koniec lat 90. XX w., kiedy to wraz z przemianami ustrojowymi zachodzącymi $\mathrm{w}$ poszczególnych państwach załamał się dychotomiczny podział na Wschód i Zachód. Pojawiła się wtedy potrzeba nazwania regionu, który przestał być elementem bloku wschodniego, ale nie stał się częścią zachodu. W ślad za upowszechnieniem się pojęcia nie poszło jednak jednoznaczne określenie granic objętego nim obszaru. Być może stało się tak, ponieważ „definiowanie regionów - jak wszelkie tego typu definicje - jest w dużej mierze umowne, a samo pojęcie regionu - niejednolite znaczeniowo - zależy od podstawowego kryterium wyróżniającego (geograficzne, etnograficzne, kulturowe, polityczne)." ${ }^{.4}$. Odwoływanie się do różnych kryteriów spowodowało, że w zależności od potrzeb i celów analizy do regionu Europy Środkowo-Wschodniej wliczano od kilku ${ }^{5}$ do osiemnastu państw ${ }^{6}$. Na potrzeby prezentowanej analizy dotyczącej rozwoju rynku kapitałowego przyjęto ten najszerszy zakres terytorialny - w badaniu uwzględniono następujące państwa: Albania, Białoruś, Bośnia i Hercegowina, Bułgaria, Chorwacja, Czarnogóra, Czechy, Estonia, Litwa, Łotwa, Macedonia, Polska, Rumunia, Serbia, Słowacja, Słowenia, Ukraina, Węgry.

Dane wykorzystane do przeprowadzenia analizy pochodziły z dużej liczby źródeł wtórnych, takich jak strony internetowe samych giełd, ich raporty roczne, publikacje naukowe, zawierające wyniki badań i analiz, opracowania i raporty przygotowywane przez firmy doradcze. Posłużono się także danymi zamieszczanymi w bazach danych Banku Światowego, Federation of European Securities Exchanges (FESE), World Federation of Exchanges (WFE) i Federation of European and Asian Stock Exchanges

\footnotetext{
${ }^{2}$ W. Streeck: Epilogue. Institutions in History: Bringing Capitalism Back In, in: G. Morgan, J. L. Campbell, C. Crouch, O. K. Pedersen, and R. Whitley (eds.), The Oxford Handbook of Comparative Institutional Analysis, Oxford, University Press Oxford 2010, s. 659-686.

${ }^{3}$ J. Barański: Polska i Europa Środkowo-Wschodnia w koncepcjach podziału Europy, [w:] Problematyka geopolityczna ziem polskich, J. Eberhardt (red.), IGiPZ PAN, Warszawa 2008, s. 121-134.

${ }^{4}$ J. Koźbiał: Europa Środkowo-Wschodnia. O koncepcji regionu z uwzględnieniem Niemiec/Austrii i Rosji. Studia Interkulturowe Europy Środkowo-Wschodniej, 2007, t. 1, s. 4.

${ }^{5}$ T. Meluzín, M. Zinecker: Trends in IPOs: The Evidence from CEE Capital Markets. Equilibrium. Quarterly Journal of Economics and Economic Policy 11/2016, No. 2, p. 327-341; J. Gajdka, P. Pietraszewski: Stock price volatility and fundamental value: evidence from Central and Eastern European Countries. Economics and Business Review 17/2017, No. 4, s. 28-46.

${ }^{6}$ J. Koźbiał, op. cit., s. 3-24; J. Barański, op. cit. , s. 121-134.
} 
$(\text { FEAS })^{7}$. Wielokrotnie konieczne było konfrontowanie danych pochodzących z różnych źródeł, ze względu na pojawiające się sprzeczne informacje. Niestety, nawet mimo zachowania daleko idącej staranności nie udało się zweryfikować danych liczbowych dotyczących rynku kapitałowego na Białorusi. W celu zachowania porównywalności wszystkie dane finansowe przyjęte do obliczeń wyrażone zostały w USD, w wartościach bieżących.

\section{Ścieżki rozwoju sformalizowanych rynków giełdowych w państwach Europy Środkowo-Wschodniej}

Historia powstania i zmian zachodzących na rynkach giełdowych w państwach Europy Środkowo-Wschodniej są bardzo zróżnicowane - trudno wskazać jedną wspólną ścieżkę rozwoju tych rynków. Różnorodność dróg, jakimi podążały giełdy w analizowanych państwach uwarunkowana była czynnikami instytucjonalnymi, politycznymi, w tym procesami prywatyzacyjnymi ${ }^{8}$ oraz koniunkturą gospodarczą. Sam moment powstania sformalizowanych rynków giełdowych w poszczególnych państwach był różny - w tabeli 1. zamieszczone zostały dane dotyczące rozpoczęcia działalności operacyjnej przez giełdy papierów wartościowych w państwach regionu (tam, gdzie utworzono więcej tego typu podmiotów, za moment uruchomienia giełdy przyjęto datę pierwszego notowania na tej giełdzie, która obecnie jest giełdą wiodąca).

Pierwsza giełda w państwach Europy Środkowo-Wschodniej to utworzona w grudniu 1989 r. Ljubljanska borza w Lublanie, należącej wówczas do Jugosławii, a obecnie będącej stolicą Słowenii. Pierwsze notowanie odbyło się na tym rynku w marcu 1990 r. Grupę podmiotów będących pionierami w tworzeniu giełd, uzupełniają Węgry, Serbia, Polska i Słowacja, w których sformalizowane rynki obrotu papierami wartościowymi powstały w latach 1990 i 1991. Niewiele później, bo w 1993 r. kolejnych pięć państw uruchomiło swoje giełdy - były to Czechy, Słowacja, Litwa, Czarnogóra i Białoruś. Grupę tę można określić mianem awangardy. Trzecia fala tworzenia zorganizowanych rynków kapitałowych w regionie Europy Środkowo-Wschodniej przypadła na lata 1995-1997, kiedy giełdy powstały na Łotwie, w Rumunii, Estonii, Macedonii, na Ukrainie, w Albanii i Bułgarii. Państwa te można zaliczyć do kategorii maruderów. Najpóźniej giełda papierów wartościowych została uruchomiona w Bośni i Hercegowinie - stało się to dopiero w 2002 r. Państwo to można zatem uznać za epigona. Od momentu utworzenia Sarajevo Stock Exchange we wszystkich państwach Europy Środkowo-Wschodniej funkcjonował już przynajmniej jeden sformalizowany rynek papierów wartościowych. Sam fakt istnienia giełd nie przesądza jednak o ich podobieństwie. Różnice były widoczne już na etapie powstawania giełd.

W części państw Europy Środkowo-Wschodniej giełdy były tworzone w wyniku inicjatywy oddolnej (np. w Bułgarii już od 1991 r. tworzyły się giełdy regionalne, których liczba sięgnęła 20), w innych państwach ich powstanie było wynikiem decyzji politycznych i poprzedzone zostało wprowadzeniem odpowiednich regulacji

\footnotetext{
$7 \quad$ https://data.worldbank.org/; http://www.fese.eu/statistics-market-research; $\quad$ https://www.worldexchanges.org/home/index.php/statistics; www.feas.org/.

${ }^{8}$ J. Prasnikar, A. Ferligoj, M. Pahor: Building a corporate network in a transition economy: The case of Slovenia. Post-communist Economies 16/2004, No. 3, s. 307-331.
} 
(np. w Polsce, gdzie w 1990 r. uchwalono niezbędne akty prawne, a w 1991 r. odbyło się pierwsze notowanie).

Tabela 1. Powstawanie wiodących giełd papierów wartościowych w państwach Europy Środkowo-Wschodniej

\begin{tabular}{|c|c|c|c|c|c|}
\hline Kategoria & Państwo & Miasto & $\begin{array}{l}\text { Aktualna nazwa wiodącej } \\
\text { gieldy }\end{array}$ & $\begin{array}{c}\text { Data } \\
\text { pierwszego } \\
\text { notowania }\end{array}$ & $\begin{array}{c}\text { Liczba spółek } \\
\text { w dniu } \\
\text { pierwszego } \\
\text { notowania } \\
\end{array}$ \\
\hline \multirow{5}{*}{ Pionierzy } & Słowenia & Lublana & $\begin{array}{c}\text { Ljubljanska borza } \\
\text { Ljubljana Stock Exchange }\end{array}$ & 29.03 .1990 & 11 \\
\hline & Węgry & Budapeszt & $\begin{array}{l}\text { Budapesti Értéktőzsde Zrt. (BÉT) } \\
\text { Budapest Stock Exchange }\end{array}$ & 21.06 .1990 & 1 \\
\hline & Serbia & Belgrad & $\begin{array}{c}\text { Београдска берза } \\
\text { Belgrade Stock Exchange }\end{array}$ & 1990 & 0 \\
\hline & Polska & Warszawa & $\begin{array}{c}\text { Giełda Papierów Wartościowych } \\
\text { w Warszawie } \\
\text { Warsaw Stock Exchange }\end{array}$ & 16.04.1991 & 5 \\
\hline & Chorwacja & Zagrzeb & $\begin{array}{c}\text { Zagrebačka burza } \\
\text { Zagreb Stock Exchange }\end{array}$ & 1991 & bd \\
\hline \multirow{5}{*}{ Awangarda } & Czechy & Praga & $\begin{array}{c}\text { Burza cenných papírů Praha } \\
\text { CEESEG Prague Stock Exchange }\end{array}$ & 06.04 .1993 & 1 \\
\hline & Słowacja & Bratysława & $\begin{array}{c}\text { Burza cenných papierov v } \\
\text { Bratislave } \\
\text { Bratislava Stock Exchange }\end{array}$ & 06.04 .1993 & bd \\
\hline & Litwa & Wilno & Nasdaq Vilnius & 14.09.1993 & 22 \\
\hline & Czarnogóra & Podgorica & $\begin{array}{c}\text { Montenegroberza } \\
\text { Montenegro Stock Exchange }\end{array}$ & 1993 & bd \\
\hline & Białoruś & Mińsk & $\begin{array}{c}\text { Белорусская валютно- } \\
\text { фондовая биржа } \\
\text { Belarusian Currency and Stock } \\
\text { Exchange } \\
\end{array}$ & 1993 & bd \\
\hline \multirow{7}{*}{ Maruderzy } & Łotwa & Ryga & Nasdaq Riga & 25.07 .1995 & 4 \\
\hline & Rumunia & Bukareszt & $\begin{array}{l}\text { Bursa de Valori Bucure ti } \\
\text { Bucharest Stock Exchange }\end{array}$ & 20.11 .1995 & 8 \\
\hline & Estonia & Tallin & Nasdaq Tallinn & 31.05 .1996 & 11 \\
\hline & Macedonia & Skopje & $\begin{array}{c}\text { Македонска берза } \\
\text { Macedonian Stock Exchange }\end{array}$ & 28.03 .1996 & bd \\
\hline & Ukraina & Kijów & $\begin{array}{l}\text { Piersza Fondowa Torgowielna } \\
\text { Sistiema } \\
\text { PFTS Ukraine Stock Exchange }\end{array}$ & 1996 & bd \\
\hline & Albania & Tirana & $\begin{array}{c}\text { Bursa e Tiranës } \\
\text { Tirana Stock Exchange }\end{array}$ & 1996 & bd \\
\hline & Bułgaria & Sofia & $\begin{array}{l}\text { Българска фондова борса } \\
\text { Bulgarian Stock Exchange }\end{array}$ & 09.10 .1997 & bd \\
\hline Epigoni & $\begin{array}{c}\text { Bośnia i } \\
\text { Hercegowina }\end{array}$ & Sarajewo & $\begin{array}{c}\text { Sarajevska Berza } \\
\text { Sarajevo Stock Exchange }\end{array}$ & 12.04 .2002 & bd \\
\hline
\end{tabular}

Źródło: opracowanie własne na podstawie danych ze stron internetowych giełd: https://www.bcse.by/en, http://www.belex.rs/eng/, http://www.bse-sofia.bg/, https://www.bse.hu/,

http://www.bsse.sk/bcpben/MainPage/tabid/104/language/en-US/Default.aspx, http://www.bvb.ro/, https://www.gpw.pl/, http://www.ljse.si/cgi-bin/jve.cgi?doc $=1468$,

http://www.montenegroberza.com/code/navigate.asp?Id=944, http://www.mse.mk/en/, http://www.nasdaqbaltic.com/en/exchange-information/about-us/, http://www.pfts.ua/en, https://www.pse.cz/?language=english\#tab-content-40375, http://www.sase.ba/v1/en-us/, https://www.tse.com.al/, http://www.zse.hr/default.aspx?id=122.

Odmienne bywały też formy organizacyjno-prawne i struktura własności giełd przy czym elementy te dodatkowo podlegały zmianom w czasie. Giełdy tworzone były jako spółki akcyjne powoływane do życia przez instytucje finansowe (np. w Czarnogórze w 1993 r. pierwszą giełdę utworzyły cztery banki), powstawały jako 
stowarzyszenia zakładane przez dealerów (np. w Ukrainie wzorowana na NASDAQ Piersza Fondowa Torgowielna Sistiema w 1996 r.), jako podmioty państwowe (np. ponad 99,9\% akcji Белорусская валютно-фондовая биржа jest własnością Republiki Białoruskiej), czy spółki non-profit (Macedonia), a nawet jako oddziały banków centralnych bez osobowości prawnej (np. w Albanii od 1996 r. do 2002 r.). W przypadku wielu giełd forma prawna ewoluowała, a w spółkach akcyjnych zmieniał się także krąg akcjonariuszy. Niektóre giełdy stały się spółkami publicznymi, których akcje notowane są na nich samych (taka sytuacja występuje np. w przypadku Giełdy Papierów Wartościowych w Warszawie, czy Bursa de Valori Bucure ti). Zjawisko to wpisuje się w ogólnoświatowy trend, zapoczątkowany w 1993 r. przez giełdę w Sztokholmie?.

Oprócz różnic $\mathrm{w}$ obszarze struktur organizacyjno-prawnych, odmiennie kształtowała się też polityka giełd $\mathrm{w}$ zakresie instrumentów, które były przedmiotem obrotu w początkowym okresie funkcjonowania tych podmiotów. Niektóre giełdy zaczynały od obrotu instrumentami dłużnymi (np. giełda w Belgradzie), inne od notowań instrumentami udziałowymi (np. GPW w Warszawie), a jeszcze inne ograniczały się wyłącznie do organizowania handlu instrumentami rynku pieniężnego (np. giełda w Czarnogórze przez pierwsze 6 lat). Były też giełdy, na których od początku w obrocie znalazły się różne instrumenty (np. w Rydze obok akcji notowane były skarbowe papiery dłużne). Z czasem na poszczególnych giełdach dochodziło do rozszerzania oferty produktowej m.in. o instrumenty pochodne, a także do tworzenia nowych segmentów notowań, czy rynków alternatywnych, a nawet platform MTF (przykładem może być Burza cenných papierov v Bratislave, gdzie tego typu platformę uruchomiono w $2008 \mathrm{r}$.).

$\mathrm{W}$ odniesieniu do samych akcji między giełdami występowały bardzo duże różnice w liczbie emitentów, która zmieniała się też niekiedy bardzo dynamicznie w obrębie poszczególnych rynków. Zmiany te niekoniecznie przy tym wiązały się z ustawicznym rozwojem rynków - przykładowo w $1994 \mathrm{r}$. w Czechach były notowane akcje 1028 spółek, a w 2001 r. już tylko 102. Inny spektakularny przypadek stanowi Litwa, gdzie liczba emitentów od 1994 r. dynamicznie rosła z poziomu 183 spółek, osiągając swoje maksimum w 1998 r. na poziomie 1365 spółek, a następnie zaczęła systematycznie spadać, by w 2006 r. wynieść już tylko 44 podmioty. Na innych rynkach liczba spółek, których akcje były przedmiotem notowań również podlegała zmianom, chociaż już nie tak dramatycznym ${ }^{10}$.

$\mathrm{W}$ ramach procesu dojrzewania czesść giełd rozwijała się samodzielnie, jako niezależne podmioty, inne zaś zaczęły szukać możliwości zawierania aliansów, tworząc regionalne grupy giełd, lub stając się członkami organizacji globalnych. Obecnie samodzielnie funkcjonują te giełdy, które przez cały czas pozostawały poza grupami międzynarodowymi oraz węgierska Budapesti Értéktőzsde Zrt., która to w 2015 r. została zrenacjonalizowana $\mathrm{w}$ wyniku odkupienia jej akcji przez Hungarian National Bank (Magyar Nemzeti Bank - MNB) od Austrian CEESEG AG and Österreichische Kontrollbank AG.

\footnotetext{
${ }^{9}$ H. Christiansen, A. Koldertsova: The Role of Stock Exchanges in Corporate Governance. OECD, Paris 2009, s. 16.

${ }^{10}$ A. Pajuste: Corporate Governance and Stock Market Performance in Central and Eastern Europe: A Study of Nine Countries, 1994-2001. 2002, http://dx.doi.org/10.2139/ssrn.310419.
} 
W przypadku giełd, które wybrały drogę rozwoju polegającą na integracji z innymi podmiotami tego typu, zazwyczaj dochodziło do tworzenia międzynarodowych grup kapitałowych. Proces integracji międzynarodowej zapoczątkowały giełdy z Wilna, Rygi i Tallina, które od początku XXI w. stopniowo formalizowały współpracę zarówno między soba, jak i z innymi giełdami z państw nadbałtyckich (m.in. ze Szwecji i Finlandia). Utworzona grupa OMX została następnie połączona $\mathrm{z}$ amerykańską giełdą NASDAQ, a obecnie giełdy z Litwy, Lotwy i Estonii funkcjonuja jako segment NASDAQ Baltic. Drugą grupe podmiotów integrujących się na drodze rozwoju sformalizowanych powiązań kapitałowych stanowiły giełdy założone w Budapeszcie, Lublanie i Pradze, które pod egidą giełdy Wiedeńskiej stworzyły w 2010 r. CEE Stock Exchange Group (CEESEG). Jednak alians w tym składzie nie utrzymał się długo - w 2015 r. akcje słoweńskiej giełdy zostały odkupione przez giełdę $\mathrm{w}$ Zagrzebiu, a węgierskiej przez bank centralny tego państwa. Próbą zbudowania struktury regionalnej ułatwiającej prowadzenie działalności przez giełdy lokalne był też SEE Link. Nie powstał on jednak jako grupa powiązana kapitałowo, tak jak to miało miejsce w dwóch opisanych wcześniej przypadkach, ale jako odrębna spółka utworzona w 2014 r. przez giełdy z Bułgarii, Macedonii i Chorwacji, mająca na celu prowadzenie wspólnej platformy notowań. W późniejszym okresie do struktury tej włączone zostały kolejne podmioty - giełdy serbska i słoweńska, giełda z Banja Luki, a także giełda grecka. Proces umiędzynarodowienia giełd obejmował nie tylko powstawanie formalnych aliansów. Wiele giełd, również tych samodzielnych operacyjnie, stawało się członkami międzynarodowych stowarzyszeń branżowych, takich jak Federation of European Stock Exchanges (FESE), World Federation of Exchanges (WFE) czy Federation of EuroAsian Stock Exchanges (FEAS).

Nie wszystkie giełdy regionu Europy Środkowo-Wschodniej rozwijają się dynamicznie, wiele z nich, szczególnie po 2007 r., odczuwa trudności i pogrążyło się w stagnacji. Do tej pory jednak tylko giełda w Tiranie zaprzestała całkowicie swojej działalności (oficjalnie zawiesiła działalność), jako jedyna w całym rejonie Europy Środkowo-Wschodniej.

\section{Struktury rynkowe}

Giełdy w państwach Europy Środkowo-Wschodniej od początku znacząco różniły się między sobą i mimo wielu form współpracy, w tym włączania się w międzynarodowe procesy integracyjne, zróżnicowanie to nie zanikło. Można jednak w populacji tych podmiotów wyodrębnić pewne bardziej jednorodne grupy. Na rysunku 1. przedstawiono klasyfikację uwzględniającą dwa wymiary - stopień koncentracji rynku oraz jego umiędzynarodowienie. W analizie nie została uwzględniona Albania, ze względu na brak aktualnie funkcjonującej w tym państwie giełdy papierów wartościowych.

Rynki w państwach Europy Środkowo-Wschodniej można podzielić na skoncentrowane - takie, w których obecnie działa tylko jedna giełda papierów wartościowych, oraz rozproszone, charakteryzujące się występowaniem więcej niż jednej giełdy, na której przedmiotem obrotu są akcje. W regionie ten pierwszy model jest obecnie znacznie bardziej rozpowszechniony - występuje w trzynastu państwach, z kolei ten drugi model, tylko w czterech. 


\begin{tabular}{|c|c|c|}
\cline { 2 - 3 } Giełdy krajowe/lokalność & Czarnogóra & Białoruś \\
Polska & Bośnia i Hercegowina \\
Rumunia & Ukraina \\
Słowacja & Węgry & \\
\hline Bułgaria & \\
Chorwacja & Czechy \\
Estonia & \\
Litwa & \\
Lotwa & \\
Macedonia & Serbia & \\
Słowenia & \\
\hline
\end{tabular}

Rysunek 1. Struktury rynków giełdowych w państwach Europy Środkowo-Wschodniej według stanu na 2018r.

Źródło: opracowanie własne.

Innym wymiarem analizy struktur rynkowych jest zakres samodzielności operacyjnej giełd. W ośmiu przypadkach giełdy (jedyne albo wiodące) funkcjonują jako niezależne podmioty. Na giełdach tych notowane są głównie akcje spółek krajowych. Bardziej rozpowszechniony jest jednak model prowadzenia działalności operacyjnej w ścisłej współpracy z innymi, zagranicznymi, giełdami. W ramach takich strategicznych aliansów, często obejmujących powiązania kapitałowe, funkcjonuje obecnie dziewięć giełd z regionu Europy Srodkowo-Wschodniej. Bardziej szczegółowy podział from integracji tych podmiotów ze światowym systemem finansowym zamieszczono w tabeli 2.

Tabela 2. Formy integracji giełd ze światowym systemem finansowym według stanu na $2018 \mathrm{r}$.

\begin{tabular}{|l|l|l|l|}
\hline $\begin{array}{l}\text { Giełdy } \\
\text { lokalne }\end{array}$ & $\begin{array}{l}\text { Znaczący udział kapitału zagranicznego } \\
\text { w strukturze akcjonariatu }\end{array}$ & Alianse regionalne & Alianse globalne \\
\hline Białoruś & Bośnia i Hercegowina & Bułgaria & \\
Polska & (ok. 20\% kapitał turecki) & Chorwacja & Estonia \\
Rumunia & Czarnogóra & Czechy & Litwa \\
Słowacja & (ok. 25\% kapitał turecki) & Macedonia & Lotwa \\
Ukraina & & Serbia & \\
Węgry & & Słowenia & \\
\hline
\end{tabular}

Źródło: opracowanie własne.

Status giełd lokalnych ma obecnie sześć podmiotów działających w państwach Europy Środkowo-Wschodniej. Są to giełdy: białoruska, polska, rumuńska, słowacka, ukraińska i węgierska, które nie mają ani powiązań operacyjnych, ani kapitałowych z podmiotami z innych państw. Samodzielne pod względem operacyjnym, ale powiązane kapitałowo z podmiotami zagranicznymi są giełdy w Bośni i Hercegowinie oraz Czarnogórze. Tego typu powiązania często stają się wstępem do dalej idącej integracji obejmującej prowadzenie wspólnej działalności - być może nastąpi tak również w tych przypadkach. W ramach aliansów strategicznych o zasięgu regionalnym funkcjonują obecnie giełdy z sześciu państw (Bułgarii, Chorwacji, Czech, Macedonii, Serbii i Słowenii), a dalsze trzy należą do aliansów globalnych - są to podmioty z Estonii Litwy i Łotwy. 
Biorąc pod uwage duże zróżnicowanie struktury sformalizowanych rynków giełdowych w państwach Europy Środkowo-Wschodniej, istotna staje się odpowiedź na pytanie: jak wybrana przez poszczególne giełdy droga rozwoju wpłynęła na ich sytuację. Zagadnieniu temu poświęcona zostanie kolejna część artykułu.

\section{Analiza komparatystyczna rynków kapitałowych państw Europy Środkowo-Wschodniej w latach 2006-2017}

Do oceny stopnia rozwoju sformalizowanych rynków kapitałowych w państwach Europy Środkowo-Wschodniej przyjęto sześć mierników: liczbę notowanych spółek, średnią wartość notowanej spółki, wartość obrotów, prędkość obrotu, bezwzględną wartość kapitalizacji giełdy, względną wartość kapitalizacji (w relacji do PKB). Mierniki te pozwalają ocenić poziom rozwoju rynków kapitałowych w różnych płaszczyznach. I tak, liczba spółek, których akcje są notowane na danej giełdzie, służy do oceny szerokości rynku. Większy wybór spółek pozwala inwestorom stosować różnorodne strategie inwestycyjne i jest jednym ze świadectw atrakcyjności strony podażowej rynku. Średnia wartość spółki z kolei pozwala ocenić potencjalną maksymalną wartość inwestycji, co jest szczególnie istotne z punktu widzenia inwestorów instytucjonalnych, zwłaszcza funduszy zbiorowego inwestowania. Niewielka wartość spółek, szczególnie gdy nie wszystkie ich akcje są wprowadzane do obrotu, oznacza bowiem konieczność zbyt daleko idącej dywersyfikacji portfela funduszu. Rozwój rynku łączył się będzie ze wzrostem średniej wartości notowanych spółek. Wartość obrotów (obliczana łącznie dla całego roku) odzwierciedla $\mathrm{z}$ kolei zainteresowanie rynkiem ze strony inwestorów. Biorąc pod uwagę, że rynek kapitałowy jest miejscem dokonywania transakcji, większe obroty świadczą o lepszym spełnianiu tej funkcji przez daną giełdę. Prędkość obrotu (velocity) to miernik pozwalający ocenić, czy operacje na rynku mają $\mathrm{w}$ większym stopniu charakter inwestycji, czy spekulacji. Wartość tego miernika pokazuje bowiem, jaka część akcji notowanych na rynku w danym okresie była, średnio rzecz biorąc, przedmiotem transakcji. Wyższy poziom tego miernika oznacza większą popularność spekulacji, związaną z wyższą płynnością obrotu i szybszym dostosowywanie się cen akcji do napływających informacji. Natomiast bezwzględna wartość kapitalizacji giełdy wynika zarówno z udziału czynników fundamentalnych, jak i rynkowych. Jest wypadkową liczby spółek, a więc i atrakcyjności rynku jako miejsca pozyskiwania kapitału oraz kursów osiaganych przez ich akcje, co wiąże się z jednej strony z kondycją emitentów, $\mathrm{z}$ drugiej zaś z nastrojami inwestorów. Zwiększająca się bezwzględna wartość kapitalizacji, zwłaszcza w dłuższym okresie, jest zatem powiązana z rozwojem giełdy. Z kolei względna wartość kapitalizacji giełdy, odniesiona do PKB państwa, w którym ona działa, jest wyznacznikiem znaczenia giełdy w jego gospodarce.

Przedstawionych sześć mierników cząstkowych wykorzystano do zbudowania miernika syntetycznego - współczynnika rozwoju rynku kapitałowego (WRRK) w którym uwzględniono zmianę wartości każdego z mierników cząstkowych w stosunku do jego wartości bazowej. Wprowadzenie tego zbiorczego miernika umożliwiło dokonanie porównania zmian, jakie zaszły na giełdach państw Europy ŚrodkowoWschodniej w analizowanym okresie. Za rok bazowy przyjęto 2006, jako ostatni przed ukształtowaniem się bańki cenowej zakończonej załamaniem i kryzysem lat 2007-2008. Rokiem referencyjnym stał się rok 2017, jako ostatni, dla którego dostępne były dane 
niezbędne do dokonania obliczeń. Sposób konstrukcji tego syntetycznego miernika przedstawiono poniżej, a wyniki obliczeń zaprezentowano w tabeli 3.

gdzie:

$$
W R R K=\frac{1}{n} \sum_{k=1}^{n} \frac{a_{k t_{r}}}{a_{k t_{b}}}
$$

WRRK - współczynnik rozwoju rynku kapitałowego

$\mathrm{n}$ - liczba mierników

$\mathrm{k}$ - kolejny numer miernika

$a_{k t_{r}}$ - wartość miernika k w roku referencyjnym (2017)

$a_{k t_{b}}$ - wartość miernika k w roku bazowym (2006)

Tabela 3. Współczynniki rozwoju rynku kapitałowego w latach 2006-2017 dla państw Europy Środkowo-Wschodniej

\begin{tabular}{|lr|lr|lr|}
\hline \multicolumn{2}{|c|}{$\begin{array}{c}\text { Lokalne giełdy zachowujące } \\
\text { samodzielność operacyjną }\end{array}$} & \multicolumn{2}{c|}{ Alianse regionalne } & \multicolumn{2}{c|}{ Alianse globalne } \\
\hline Ukraina & $20 \%$ & Słowenia & $54 \%$ & Litwa & $37 \%$ \\
Bośnia i Hercegowina & $39 \%$ & Chorwacja & $62 \%$ & Estonia & $48 \%$ \\
Czarnogóra & $58 \%$ & Serbia & $69 \%$ & Lotwa & $85 \%$ \\
Węgry & $64 \%$ & Czechy & $78 \%$ & & \\
Słowacja & $77 \%$ & Bułgaria & $133 \%$ & \\
Rumunia & $96 \%$ & Macedonia & $165 \%$ & & \\
Polska & $132 \%$ & & & & \\
\hline
\end{tabular}

Źródło: opracowanie własne.

Współczynnik rozwoju rynku kapitałowego kształtował się w odniesieniu do poszczególnych państw Europy Środkowo-Wschodniej na bardzo zróżnicowanym poziomie. Najniższy był na Ukrainie, ale specyfika sytuacji tego państwa sprawia, że stanowi ono przypadek mało reprezentatywny. Wśród giełd zachowujących samodzielność operacyjną najgorsze wyniki (pomijając Ukrainę) odnotowano w Bośni i Hercegowinie oraz w Czarnogórze, najlepsze zaś w Polsce i Rumunii. W dwóch pierwszych państwach giełdy między rokiem 2006 a 2017 skurczyły się - o ponad połowę w Bośni i Hercegowinie i o blisko połowę w Czarnogórze. W Polsce w tym okresie nastąpił rozwój rynku, a w Rumuni widoczna była jego stagnacja. Na Węgrzech i na Słowacji rynki skurczyły się, ale mniej, niż w państwach bałkańskich.

Nieco lepiej (przeciętnie), niż giełdy zachowujące samodzielność operacyjna, radziły sobie rynki będące częścią aliansów regionalnych. Dwa z nich - w Słowenii i w Chorwacji - skurczyły się o blisko połowę, dwa kolejne o około 1/4, a osiagające najlepsze wyniki Bułgaria i Macedonia rozwinęły się odpowiednio o ponad $30 \%$ i o 65\%. Najbardziej niekorzystne zmiany nastąiły w latach 2006-2017 na giełdach, które stały się częścią aliansów globalnych. Na wszystkich tych rynkach odnotowano regres najsilniejszy na Litwie, a najsłabszy na Łotwie.

Miernik zagregowany, jakim jest współczynnik rozwoju rynku kapitałowego, odzwierciedla ogólną panująca na nim sytuację, a jego zmiany wskazują kierunek, w jakim rynek ten zmierza. Tego typu syntetyczny obraz można poddać dezagregacji, która pozwala na bardziej szczegółową analizę przekształceń, jakie w latach 2006-2017 zaszły na poszczególnych giełdach. Analizowane zmienne zostały zaprezentowane dla 
każdego rynku z osobna - dane dla roku 2017 odniesiono do danych z roku 2006 (przyjętego za rok bazowy), którym przypisano wartość $100 \%$. Wyniki takiego działania w odniesieniu do państw, w których wiodące giełdy zachowały samodzielność operacyjną przedstawiono na wykresie 1. Foremny sześcian widoczny na każdym z wykresów stanowi punkt odniesienia właściwy dla każdego rynku z osobna, zawierając dane wyjściowe z 2006 r. Na jego tle widoczny jest nieregularny kształt, obrazujący stan rynku w roku 2017. Pozwala to ocenić zmiany, jakie nastąpiły w sześciu analizowanych wymiarach na rynku kapitałowym w danym państwie.

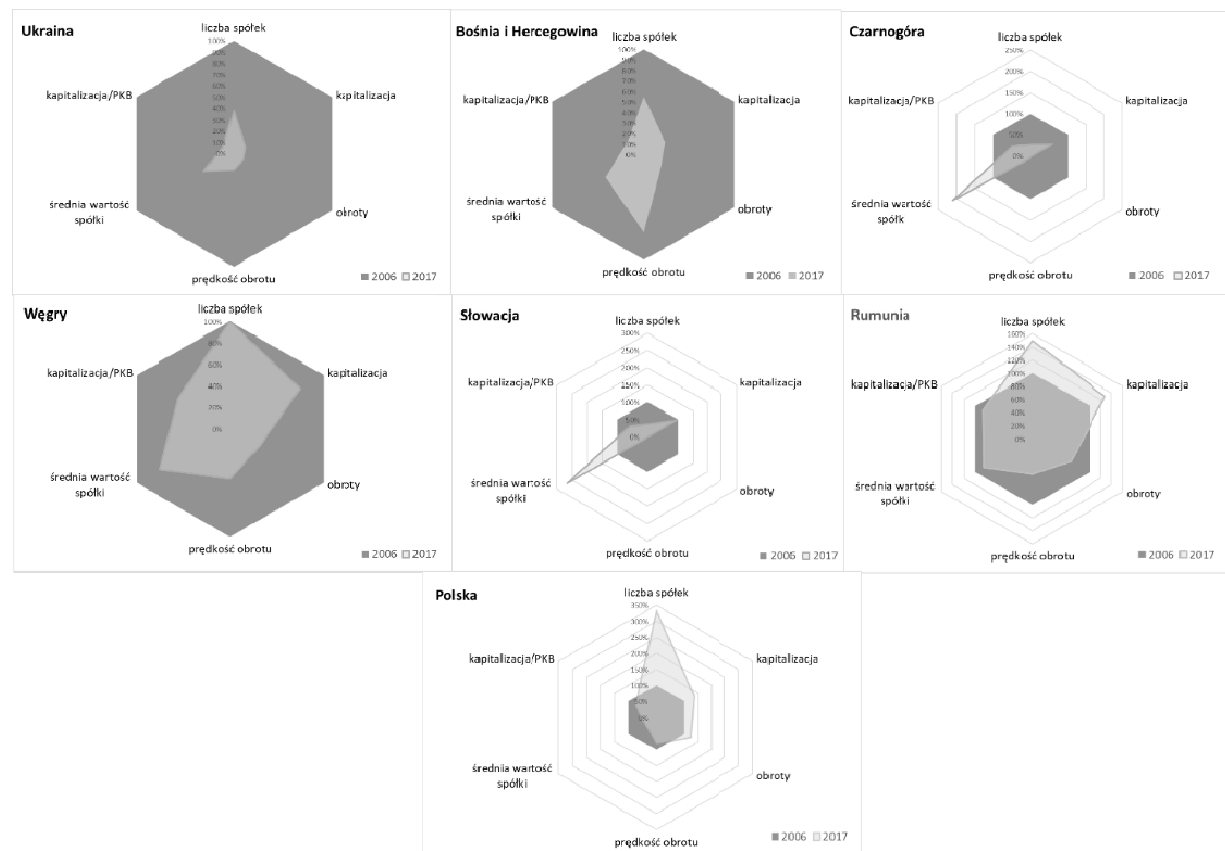

Wykres 1. Porównanie stanu rozwoju lokalnych giełd zachowujących samodzielność operacyjną (lata 2006-2017)

Źródło: opracowanie własne.

Dane zawarte na wykresie 1. dowodzą, że opisywane wcześniej kurczenie się, bądź rozwój giełd w poszczególnych państwach miały swoją specyfikę. Poza rynkiem ukraińskim oraz giełdą w Bośni i Hercegowinie, w przypadku których regres dotyczył wszystkich wymiarów, zmiany nie były jednoznacznie negatywne. Na przykład w Czarnogórze i na Słowacji mimo ogólnego kurczenia się rynku znacząco wzrosła średnia wartość spółki, co może wskazywać na jakościową poprawę po stronie podażowej - pojawienie się na giełdzie akcji większych, bardziej wiarygodnych podmiotów. Jednocześnie widoczne zmniejszenie się na tych dwóch rynkach wielkości i prędkości obrotu świadczy o występujących na nich ograniczeniach po stronie popytowej. Z kolei na Węgrzech ogólnemu kurczeniu się rynku nie towarzyszył spadek liczby notowanych na nim spółek, co mogłoby wskazywać na utrzymujące się ich zainteresowanie giełdą jako miejscem pozyskiwania kapitału. Można zatem sądzić, że także w przypadku tego państwa bariery rozwoju rynku leżą bardziej po stronie 
popytowej, niż podażowej. Sytuację na rynku rumuńskim dotkniętym stagnacją cechował pewien wzrost liczby spółek, połączony ze zwiększeniem się kapitalizacji giełdy przy jednoczesnym niewielkim spadku obrotów. Również na tym rynku strona podażowa wydaje się więc w mniejszym stopniu ograniczać jego rozwój, niż strona popytowa. Na tle opisywanych dotychczas giełd wyróżniał się rynek polski - jako jedyny wykazywał oznaki ożywienia, którego główną siłą napędową była dynamicznie rosnąca liczba spółek oraz towarzyszący jej, ale już nie tak znaczący wzrost kapitalizacji i obrotów. Równocześnie jednak na warszawskiej giełdzie zmniejszyła się średnia wartość spółki, co dowodzi, że wśród nowych emitentów poszukujących kapitału dominowały podmioty o mniejszych rozmiarach.

Podobnie, jak giełdy zachowujące samodzielność operacyjną, również rynki należące do aliansów regionalnych charakteryzowało duże zróżnicowanie. Obrazuje to wykres 2 .

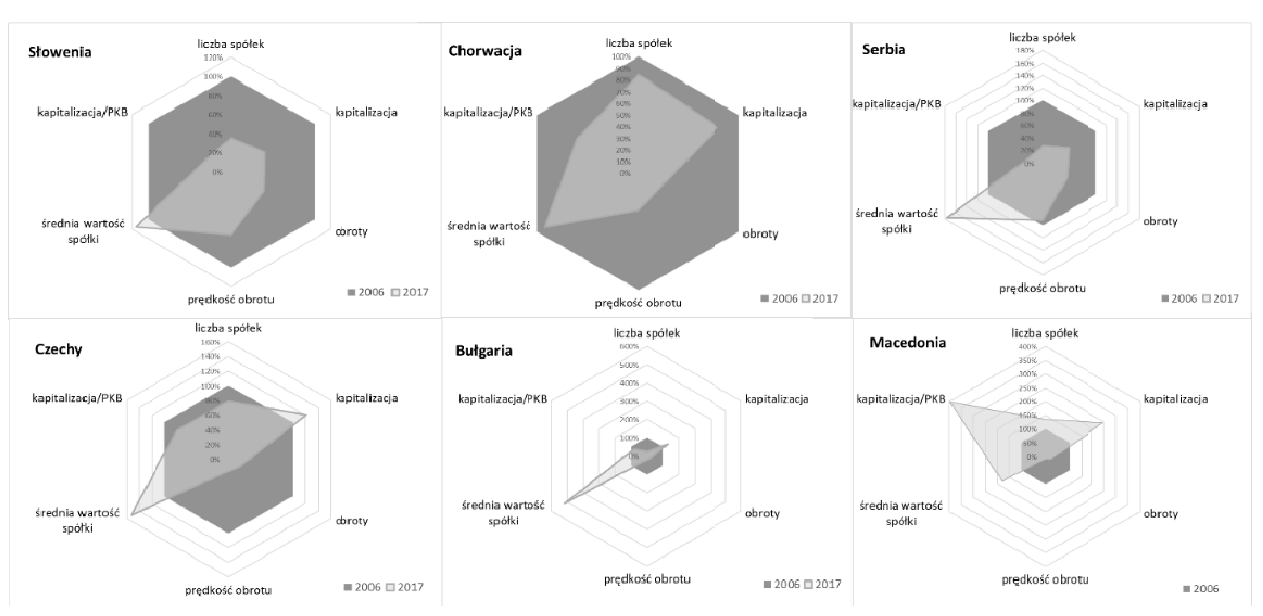

Wykres 2. Porównanie stanu rozwoju giełd należących do aliansów regionalnych (lata 2006-2017) Źródło: opracowanie własne

W grupie giełd wchodzących w skład aliansów regionalnych najbardziej skurczył się rynek słoweński, chociaż należy odnotować, że nawet na nim poprawie uległ jeden z parametrów - zwiększyła się nieco średnia wartość spółki. Wyraźny regres nastapił także na rynku chorwackim, w przypadku którego profil zmian okazał się podobny do zaobserwowanego na rynku węgierskim, z tym, że na Zagreb Stock Exchange, w odróżnieniu od giełdy budapesztańskiej niewielkiemu zmniejszeniu uległa również liczba notowanych spółek. Z kolei rynek serbski pod względem zachodzących na nim zmian wykazywał pewne podobieństwa do giełdy czarnogórskiej - na Belgrade Stock Exchange odnotowano jednak znacznie mniejszy spadek wielkości i prędkości obrotu, a udział kapitalizacji tej giełdy w PKB obniżył się w większym stopniu, niż w przypadku rynku czarnogórskiego. Regres widoczny był także na rynku czeskim. Mimo to, wzrosła na nim średnia wartość spółki, zwiększyła się też kapitalizacja praskiej giełdy. Podobne zjawisko było widoczne na rynku bułgarskim, z tym że wystąpił na nim nieporównanie silniejszy wzrost średniej wartości spółki, co zadecydowało o rozwoju całej giełdy. 
Obok rynku bułgarskiego rozwinął się też rynek macedoński. Nie tylko wzrosła średnia wartość notowanej na tym rynku spółki i kapitalizacja całego rynku, ale zwiększył się również udział tej kapitalizacji w PKB oraz nastąpił przyrost liczby spółek, których akcje znalazły się w obrocie. Cechą wspólną wszystkich giełd należących do aliansów regionalnych okazał się znaczny spadek wielkości obrotów i zmniejszenie się prędkości obrotu. Oznacza to, że udział w aliansach regionalnych nie przynosi tak istotnego dla rynków Europy Środkowo-Wschodniej efektu w postaci zwiększonego popytu wynikającego ze wzrostu zainteresowania inwestorów międzynarodowych, czy silniejszej mobilizacji kapitału krajowego.

Ostatnią grupę analizowanych giełd z państw Europy Środkowo-Wschodniej stanowiły podmioty, które należą do aliansu globalnego. Zmiany, jakie zaszły na tych giełdach obrazuje wykres 3 .
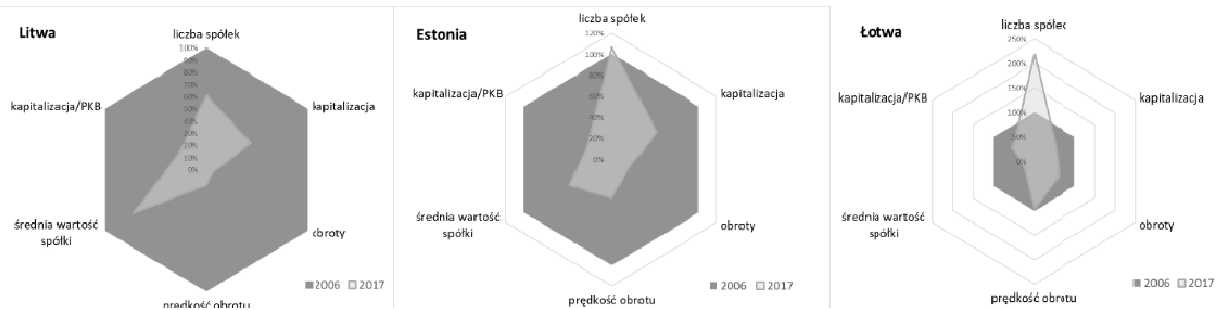

Wykres 3. Porównanie stanu rozwoju giełd należących do aliansu globalnego (lata 2006-2017) Źródło: opracowanie własne.

Wszystkie z giełd należących do aliansu globalnego doświadczyły regresu, który najsilniej zaznaczył się na rynku litewskim - każdy z sześciu mierzonych parametrów uległ na tym rynku pogorszeniu. W najmniejszym stopniu spadły średnia wartość spółki i liczba emitentów. Podobna sytuacja wystapiła na rynku estońskim, na którym jednak odnotowano nieznaczny wzrost liczby emitentów, co w połączeniu z ograniczonym spadkiem średniej wartości spółki spowodowało, że regres w kapitalizacji tallińskiej giełdy był mniejszy, niż w przypadku giełdy litewskiej. Spośród tych trzech rynków najmniej pogorszyła się sytuacja na giełdzie łotewskiej, na której wyraźnie wzrosła liczba notowanych spółek. Rynek ten odróżniało od pozostałych giełd państw nadbałtyckich także bardzo niewielkie zmniejszenie się prędkości obrotu. Wyraźniej jednak, niż na innych rynkach, które stały się częścią aliansu globalnego zaznaczył się na rynku łotewskim spadek średniej wartości spółki.

Alians globalny, do którego należą giełdy ze wszystkich trzech państw nadbałtyckich, oznacza dostęp do międzynarodowej platformy transakcyjnej. Funkcjonowanie w jego strukturach powinno zatem pozytywnie wpływać na wartość obrotów, tymczasem w żadnym z trzech państw należących do tej grupy, tego typu efekt nie wystąpił. Co więcej, zarówno łączna wartość obrotów, jak i prędkość obrotu zmalały (chociaż na Łotwie spadek prędkości obrotu był minimalny). Można by również oczekiwać, że obecność w aliansie globalnym przyczyni się do wzrostu średniej wartości spółek, odzwierciedlającego zwiększenie się ich wiarygodności wynikające z transferu reputacji giełdy NASDAQ na giełdy państw nadbałtyckich, a pośrednio i na spółki, których akcje są na nich notowane. Niestety, również ten efekt nie wystąpił, co 
przełożyło się na brak wzrostu kapitalizacji wszystkich trzech giełd - ich kapitalizacja wręcz spadła.

\section{Podsumowanie}

Początki tworzenia sformalizowanych rynków giełdowych, na których przedmiotem obrotu mogły być akcje, przypadły w państwach Europy Środkowo-Wschodniej na lata 90. XX w. Powstanie zorganizowanych rynków kapitałowych miało być w tych państwach jednym $\mathrm{z}$ istotnych ogniw dokonujących się przemian ustrojowych, pozwalając między innymi na sprawne przeprowadzenie procesów prywatyzacyjnych. Giełdy papierów wartościowych miały być też miejscem pozyskiwania kapitału dla nowopowstających przedsiębiorstw prywatnych, stanowiąc dopełnienie zorientowanych bankowo ${ }^{11}$ krajowych systemów finansowania gospodarki. Od momentu powstania rynki giełdowe $\mathrm{w}$ poszczególnych państwach różniły się między sobą. Odmienna była także droga ich rozwoju.

Największą słabością rynków wschodzących, w tym również w Europie ŚrodkowoWschodniej, jest ustawiczny brak płynności ${ }^{12}$. Jego źródła mogą mieć charakter zarówno podażowy, jak i popytowy. W pierwszym przypadku wiążą się z niedostateczną liczbą spółek, których akcje znajdują się w obrocie, niewielkimi rozmiarami tych podmiotów, sprawiającymi, że liczba i wartość emitowanych przez nie akcji są małe oraz z polityką emitentów i ich właścicieli, polegająca na wprowadzaniu do obrotu tylko znikomej części akcji. Po stronie popytowej za niedostateczną płynność odpowiadają zaś głównie: ograniczony kapitał inwestorów oraz ich strategia (dominacja inwestycji nad spekulacja). Zadaniem chcących się rozwijać giełd jest więc przyciagganie nowych, wiarygodnych, dużych lub mających znaczący potencjał wzrostu emitentów, kształtowanie zasad ładu korporacyjnego umożliwiających zachowanie kontroli nad spółką za pomocą mniejszych pakietów akcji, przy jednoczesnym zabezpieczeniu interesów akcjonariuszy mniejszościowych oraz przyciaganie nowego kapitału, dbając o zachowanie równowagi między napływem kapitału inwestycyjnego i spekulacyjnego. Odpowiadając na te wyzwania giełdy z regionu Europy Środkowo-Wschodniej podazżały trzema drogami: wybierały rozwój organiczny, stawiając na samodzielność operacyjna, tworzyły alianse regionalne, bądź wchodziły do nich, stawały się uczestnikami aliansów globalnych. Wyniki przeprowadzonych badan dotyczących zmian, jakie zaszły na tych giełdach między rokiem 2006 a 2017 dowodzą, że żadne z rozwiązań nie prowadziło do pełnego sukcesu. Wyniki te wskazują również, że giełdy generalnie lepiej radziły sobie z przezwyciężaniem barier po stronie podażowej - na części rynków wzrosła liczba emitentów i średnia wartość spółki, niż popytowej (niemal na wszystkich rynkach spadła zarówno wielkość, jak i prędkość obrotu).

\footnotetext{
${ }^{11}$ Z. Jeremić, I. Terzić: Financial Reporting of Listed Companies on The Stock Exchanges in European Union and Southeast Europe, International Scientific Conference FINIZ 2014, DOI:10.15308/finiz-2014-64-66.

${ }^{12} \mathrm{~S}$. Alderighi: A note on how to enhance liquidity in emerging markets by levering on trading participants. „Economics Bulletin” 37/2017, No. 4, p. 2526-2532.
} 


\section{Bibliografia}

Alderighi S.: A note on how to enhance liquidity in emerging markets by levering on trading participants. Economics Bulletin 37/2017, No. 4, p. 2526-2532.

Barański J.: Polska i Europa Środkowo-Wschodnia w koncepcjach podziatu Europy, [w:] Problematyka geopolityczna ziem polskich, J. Eberhardt (red.), IGiPZ PAN, Warszawa 2008, s. 121-134.

Belarusian Currency and Stock Exchange, https://www.bcse.by/en

Belgrade Stock Exchange, http://www.belex.rs/eng/

Bratislava Stock Exchange, http://www.bsse.sk/bcpben/MainPage/tabid/104/language/enUS/Default.aspx

Bucharest Stock Exchange, http://www.bvb.ro/

Budapest Stock Exchange, https://www.bse.hu/

Bulgarian Stock Exchange, http://www.bse-sofia.bg/

CEESEG Prague Stock Exchange, https://www.pse.cz/?language=english\#tab-content-40375

Christiansen H., Koldertsova A.: The Role of Stock Exchanges in Corporate Governance. OECD, Paris 2009.

Federation of European and Asian Stock Exchanges, www.feas.org/.

Federation of European Securities Exchanges, http://www.fese.eu/statistics-market-research.

Gajdka J., Pietraszewski P.: Stock price volatility and fundamental value: evidence from Central and Eastern European Countries. Economics and Business Review 17/2017, No. 4, s. 28-46.

Jeremić Z., Terzić I.: Financial Reporting of Listed Companies on The Stock Exchanges in European Union and Southeast Europe, International Scientific Conference FINIZ 2014, DOI:10.15308/finiz-2014-64-66.

Jessop B.: Rethinking the diversity of capitalism: varieties of capitalism, variegated capitalism, and the world market, in: C. Lane, G.T. Wood (eds.), Capitalist Diversity and Diversity within Capitalism, Routledge, London 2011, pp. 209-237.

Koźbiał J.: Europa Środkowo-Wschodnia. O koncepcji regionu z uwzględnieniem Niemiec/Austrii $i$ Rosji. Studia Interkulturowe Europy Środkowo-Wschodniej 2007, t. 1, s. 3-24.

Ljubljana Stock Exchange, http://www.ljse.si/cgi-bin/jve.cgi?doc=1468

Macedonian Stock Exchange, http://www.mse.mk/en/

Meluzín T., Zinecker M.: Trends in IPOs: The Evidence from CEE Capital Markets. Equilibrium. Quarterly Journal of Economics and Economic Policy 11/2016, No. 2, p. 327-341.

Montenegro Stock Exchange, http://www.montenegroberza.com/code/navigate.asp?Id=944

NASDAQ Baltic, http://www.nasdaqbaltic.com/en/exchange-information/about-us/

Pajuste A.: Corporate Governance and Stock Market Performance in Central and Eastern Europe: A Study of Nine Countries, 1994-2001. 2002, http://dx.doi.org/10.2139/ssrn.310419.

PFTS Ukraine Stock Exchange, http://www.pfts.ua/en

Prasnikar J., Ferligoj A., Pahor M.: Building a corporate network in a transition economy: The case of Slovenia. Post-communist Economies 16/2004, No. 3, s. 307-331.

Sarajevo Stock Exchange, http://www.sase.ba/v1/en-us/

Streeck W.: Epilogue. Institutions in History: Bringing Capitalism Back In, in: G. Morgan, J. L. Campbell, C. Crouch, O. K. Pedersen, and R. Whitley (eds.), The Oxford Handbook of Comparative Institutional Analysis, Oxford University Press, Oxford 2010, s. 659-686.

Tirana Stock Exchange, https://www.tse.com.al/

Warsaw Stock Exchange, https://www.gpw.pl/

World Bank Open Data, https://data.worldbank.org/.

World Federation of Exchanges, https://www.world-exchanges.org/home/index.php/statistics

Zagreb Stock Exchange, http://www.zse.hr/default.aspx?id=122 


\section{Summary}

Well-developed capital markets are an important element of the economy, as a source of financing for enterprises complementary to the banking system. In addition, they perform other important functions: they allow the valuation of capital and risk, facilitate the transfer of ownership of shares, and are also a place of investment and speculation. The markets of developed countries are often subjected to various analyses, which allow to assess both the state of development of these markets and their functioning. There are much fewer such analysis for emerging markets. The leastresearched markets in this area are Central and Eastern Europe. In order to at least partially fill this gap, analysis of the development of organized stock exchange markets in these countries in the period 2006-2017 was carried out. A wide territorial scope was adopted - the study covered: Albania, Belarus, Bosnia and Herzegovina, Bulgaria, Croatia, Montenegro, the Czech Republic, Estonia, Lithuania, Latvia, Macedonia, Poland, Romania, Serbia, Slovakia, Slovenia, Ukraine, and Hungary.

The data used to conduct the analysis came from a large number of secondary sources, such as the websites of the exchanges themselves, their annual reports, scientific publications, studies and reports of consulting companies, as well as databases of international organizations. The results of the analysis show that the stock exchanges from the Central and Eastern Europe region followed three paths: (1) they chose organic development, focusing on operational independence, (2) joined regional alliances, (3) became global alliance participants. The results of research on changes that took place on these exchanges between 2006 and 2017 prove that none of the solutions led to full success. These results also indicate that the stock exchanges generally coped better with overcoming barriers on the supply side (the number of issuers and the company's average value increased on part of the markets) than on the demand side (both the volume and the speed of turn decreased on almost all exchanges).

Keywords: Central and Eastern Europe, capital market, stock exchange, velocity, organized market

Informacja o autorze:

dr hab. Agata Adamska, prof. nadzw. SGH

Instytut Finansów Korporacji i Inwestycji

Zakład Zarządzania Finansami Przedsiębiorstwa

Kolegium Nauk o Przedsiębiorstwie

Szkoła Główna Handlowa w Warszawie

Al. Niepodległości 162, Warszawa

e-mail: agata.adamska@sgh.waw.pl

ORCID: 0000-0002-7421-5878 